\title{
Functional role of newly formed pore complexes in postmitotic nuclear reorganization
}

\author{
Ricardo Benavente ${ }^{1}$, Marie-Christine Dabauvalle ${ }^{1}$, Ulrich Scheer ${ }^{1}$, and Nathalie Chaly ${ }^{2}$ \\ ${ }^{1}$ Institute of Zoology I, University of Würzburg, D-8700 Würzburg, Federal Republic of Germany \\ ${ }^{2}$ Department of Biology, Carleton University, Ottawa K1S 5B6, Canada
}

\begin{abstract}
Many nuclear proteins are released into the cytoplasm at prometaphase and are transported back into the daughter nuclei at the end of mitosis. To determine the role of this reentry in nuclear remodelling during early interphase, we experimentally manipulated nuclear protein uptake in dividing cells. Recently we and others have shown that signal-dependent, pore complex-mediated uptake of nuclear protein is blocked in living cells on microinjection of the lectin wheat germ agglutinin (WGA), or of antibodies such as PI1 that are directed against WGA-binding pore complex glycoproteins. In the present study, we microinjected mitotic PtK ${ }_{2}$ cells with WGA or antibody PI1 and followed nuclear reorganization of the daughter cells by immunofluorescence and electron microscopy. The inhibitory effect on nuclear protein uptake was monitored by co-injection of the karyophilic protein nucleoplasmin. When injected by itself early in mitosis, nucleoplasmin became sequestered into the daughter nuclei as they entered telophase. In contrast, nucleoplasmin was excluded from the daughter nuclei in the presence of WGA or antibody PI1. Although $\mathrm{PtK}_{2}$ cells with blocked nuclear protein uptake completed cytokinesis, their nuclei showed a telophaselike organization characterized by highly condensed chromatin surrounded by a nuclear envelope containing a few pore complexes. These findings suggest that pore complexes become functional as early as telophase, in close coincidence with nuclear envelope reformation. They further indicate that the extensive structural rearrangement of the nucleus during the telophase-G1 transition is dependent on the influx of karyophilic proteins from the cytoplasm through the pore complexes, and is not due solely to chromosome-associated components.
\end{abstract}

\section{Introduction}

A wealth of evidence has firmly established that influx of proteins from the cytoplasm into the nucleus is of fundamental importance for the regulation of a number of cellular processes (e.g. Goldstein 1974; Harris 1974; Ringertz and Savage 1976; Bonner 1978; Scheer et al. 1983; Setterfield et al. 1983; Woodcock et al. 1984; Gurdon 1986), but only recently has it become feasible to modulate nucleocy-

Abbreviations: WGA wheat germ agglutinin; GlcNAc N-acetylglucosamine

Offprint requests to: $\mathrm{R}$. Benavente toplasmic exchange processes of macromolecules experimentally. It is now clear that wheat germ agglutinin (WGA), a lectin binding to $\mathrm{N}$-acetylglucosamine (GlcNAc) sugar residues, binds to nuclear pore complexes and interferes with the signal-dependent translocation of karyophilic proteins into isolated nuclei in vitro (Finlay et al. 1987; Newmeyer and Forbes 1988). Microinjection of WGA has also been shown to inhibit nuclear protein uptake in vivo while nucleocytoplasmic equilibration of "amphiphilic" proteins as well as of exogenous macromolecules such as dextran remain unaffected (Yoneda et al. 1987; Dabauvalle et al. 1988b; Wolff et al. 1988). Since WGA binds to a whole set of pore complex proteins with cytoplasmically or nucleoplasmically exposed O-linked GlcNAc moieties (Davis and Blobel 1987; Finlay et al. 1987; Hanover et al. 1987; Snow et al. 1987; Scheer et al. 1988; for review see Hart et al. 1988), these studies could not identify the particular glycoprotein(s) involved in the translocation step. Recently, however, a monoclonal antibody reacting with a single pore complex-associated glycoprotein of $\mathrm{M}_{\mathrm{r}} 68000$ has been shown to inhibit nuclear protein uptake after microinjection into Xenopus oocytes (Dabauvalle et al. 1988a). This result suggested a crucial role of this major glycoprotein, which is located in the pore channel proper, for nuclear protein transport (Dabauvalle et al. 1988a; see also Featherstone et al. 1988).

The availability of reagents interfering with nuclear protein transport in living cells now offers the possibility of studying the biological effects produced by blockade of pore-mediated protein transport. At present it is not known at which point in the assembly of the postmitotic nuclear envelope do nuclear pore complexes resume their function as gateways for nucleocytoplasmic exchange. In particular, it is unclear whether the nuclear pore complexes are necessary during such early steps in the reestablishing of interphase nuclear organization and function such as chromosome decondensation, nucleolar reconstitution, and assembly of nucleoplasmic functional domains.

In preliminary experiments, we observed that WGA or our monoclonal antibody inhibited the development of Xenopus embryos when microinjected at the two-cell stage and noted that the developmental arrest apparently became effective only after completion of a cell division. We therefore became interested in determining the postmitotic stage during which nuclear protein import is essential for normal development. However, the large, opaque and yolk-laden Xenopus embryos are not suitable to address this issue. We 
therefore used somatic mammalian tissue culture cells which can be microinjected during mitosis and their fate then analyzed individually by immunofluorescence and electron microscopy (see Benavente and Krohne 1986).

\section{Materials and methods}

Biological materials. Rat kangaroo kidney epithelial cells $\left(\mathrm{PtK}_{2}\right)$ were grown on coverslips (Franke et al. 1978). Eggs obtained from Xenopus laevis were fertilized in vitro and freed of their jelly coat with a $2 \%$ cysteine solution prior to microinjection as previously described (Newport and Kirschner 1982).

Antibodies. Murine monoclonal antibody PI1 (IgM) was raised against a mouse lymphocyte nuclear matrix fraction and has been characterized in detail (Chaly et al. 1984, 1986). Experiments were carried out using PI1 ascites fluid purified by hydroxylapatite chromatography, concentrated and lyophilized as previously described (Stanker et al. 1985). In Xenopus oocytes it has been shown by protein blotting and immunogold electron microscopy that the reconstituted lyophilized PI1 column fraction recognizes specifically a major $M_{r} 68000$ glycoprotein located in the pore complex channel (Dabauvalle et al. 1988a). Guinea pig antibodies against nucleoplasmin were kindly provided by Georg Krohne (German Cancer Research Center, Heidelberg, FRG; see Krohne 1985).

Gel electrophoresis and immunoblotting. $\mathrm{PtK}_{2}$ cells were scraped off from petri dishes into a buffer containing $20 \mathrm{mM} \mathrm{KCl}, 0.3 \%$ Triton X-100, $5 \mathrm{mM}$ EDTA, $20 \mathrm{mM}$ Tris, $\mathrm{pH} 7.4$, and the cells were homogenized in a Dounce homogenizer. After centrifugation $(3000 \mathrm{~g}$; $10 \mathrm{~min})$, the pellet representing a crude nuclear fraction was resuspended in sample buffer. Proteins were analyzed by SDS-polyacrylamide $(10 \%)$ gel electrophoresis according to Laemmli (1970). For immunoblotting, proteins were electrophoretically transferred to a nitrocellulose filter (Towbin et al. 1979) and probed with antibody PI1 (for details see Dabauvalle et al. 1988a).

Microinjection. Mitotic $\mathrm{PtK}_{2}$ cells were microinjected at prometaphase or metaphase using an Eppendorf Microinjector 5242 (Eppendorf, Hamburg, FRG) with glass capillaries GC150 (Clark Electromedical Instruments, Reading, UK) or Femtotips (Eppendorf) (Benavente and Krohne 1986). WGA conjugated to fluorescein isothiocyanate (FITC; Medac, Hamburg, FRG) was dissolved in PBS (137 mM NaCl, $2.7 \mathrm{mM} \mathrm{KCl}, 7 \mathrm{mM} \mathrm{Na}{ }_{2} \mathrm{HPO}_{4}, 1.5 \mathrm{mM}$ $\mathrm{KH}_{2} \mathrm{PO}_{4}$ ) at concentrations ranging from 0.5 to $3 \mathrm{mg} / \mathrm{ml}$. Nucleoplasmin (prepared from Xenopus oocytes according to Krohne and Franke 1980a) was used at $3 \mathrm{mg} / \mathrm{ml}$ and antibody PI1 at $10 \mathrm{mg} / \mathrm{ml}$ in PBS. Control cells were injected with comparable amounts of non-immune mouse IgM (Sigma, Munich, FRG) or monoclonal IgM antibodies to DNA (Benavente and Krohne 1986; Benavente et al. 1989). In some experiments nucleoplasmin was injected together with WGA or antibody PI1.

Fertilized Xenopus eggs were transferred into modified Ringer solution (MMR; Newport and Kirschner 1982) containing 5\% Ficoll. At the two-cell stage, one blastomere of an embryo was injected into the pigmented half with $30 \mu \mathrm{l}$ of WGA $(2 \mathrm{mg} / \mathrm{ml}$ diluted in $10 \mathrm{mM}$ Pipes, $\mathrm{pH} 7.2)$ or with antibody PI1 $(10 \mathrm{mg} / \mathrm{ml}$ in PBS). Control blastomeres received $30 \mu \mathrm{l}$ buffer or non-specific immunoglobulins.

Immunofluorescence microscopy. Cells were fixed in PBS containing 3\% formaldehyde (prepared from paraformaldehyde) and permeabilized in PBS containing $0.1 \%$ Triton $\mathrm{X}-100$. The cells were then incubated with antibody PI1 for $30 \mathrm{~min}$ followed by anti-mouse $\mathrm{IgG} / \mathrm{IgM}$ antibodies conjugated to Texas red or FITC (Dianova, Hamburg, FRG).

Microinjected cells were fixed and permeabilized as described above after different incubation times. The distribution of microinjected nucleoplasmin was visualized by incubating coverslips with antibodies directed against nucleoplasmin followed by anti-guinea pig secondary antibodies conjugated to Texas red (Dianova). The distribution of microinjected PI1 antibody was visualized by anti-mouse IgG/ IgM antibodies conjugated to Texas red or FITC. Photographs were taken with a Zeiss Axiophot equipped with epifluorescence optics (Carl Zeiss, Oberkochen, FRG).

Electron microscopy. Cells microinjected with WGA or PI1 antibodies were fixed in $2.5 \%$ glutaraldehyde for $15 \mathrm{~min}$ followed by $2 \%$ osmium tetroxide $(15 \mathrm{~min})$ and processed for transmission electron microscopy as previously described (Benavente and Krohne 1986).

For scanning electron microscopy Xenopus embryos were placed in $20 \%$ MMR containing 5\% Ficoll and the vitelline membrane was mechanically removed using two fine forceps. Then the embryos were fixed overnight with $6.25 \%$ glutaraldehyde and dehydrated through an acetone series. Finally, the embryos were dried by the critical point method with $\mathrm{CO}_{2}$ and sputter-coated with gold according to standard procedures. Micrographs were taken with a Zeiss EM 10 electron microscope and a Cambridge ISI Super IIIA scanning microscope.

\section{Results}

\section{Microinjection into Xenopus embryos}

In the first set of experiments, WGA or antibody PI1 was microinjected into one blastomere of Xenopus embryos at the two-cell stage. The blastomere injected with either of these reagents ceased to divide while the non-injected control half of the embryo developed normally (Fig. $1 \mathrm{~b}$ ). When WGA or PI1 was introduced into a blastomere toward the end of the cell cycle, the injected cell often went through the subsequent cleavage before cell cycle arrest occurred. Control injections with buffer or non-immune immunoglobulins showed no effects on embryonic development (Fig. 1a).

\section{Characterization and localization of the antigen recognized} by antibody PI1 in PtK $\mathrm{K}_{2}$ cells

Since $\mathrm{PtK}_{2}$ cells were used in all subsequent experiments, the reactivity of antibody PI1 with antigens derived from this mammalian cell line was tested by the immunoblotting technique and by immunofluorescence microscopy. As shwon in Figure 2, the antibody reacted specifically with a single polypeptide of $M_{r} 68000$ (lane $2^{\prime}$, arrow). A poly- 

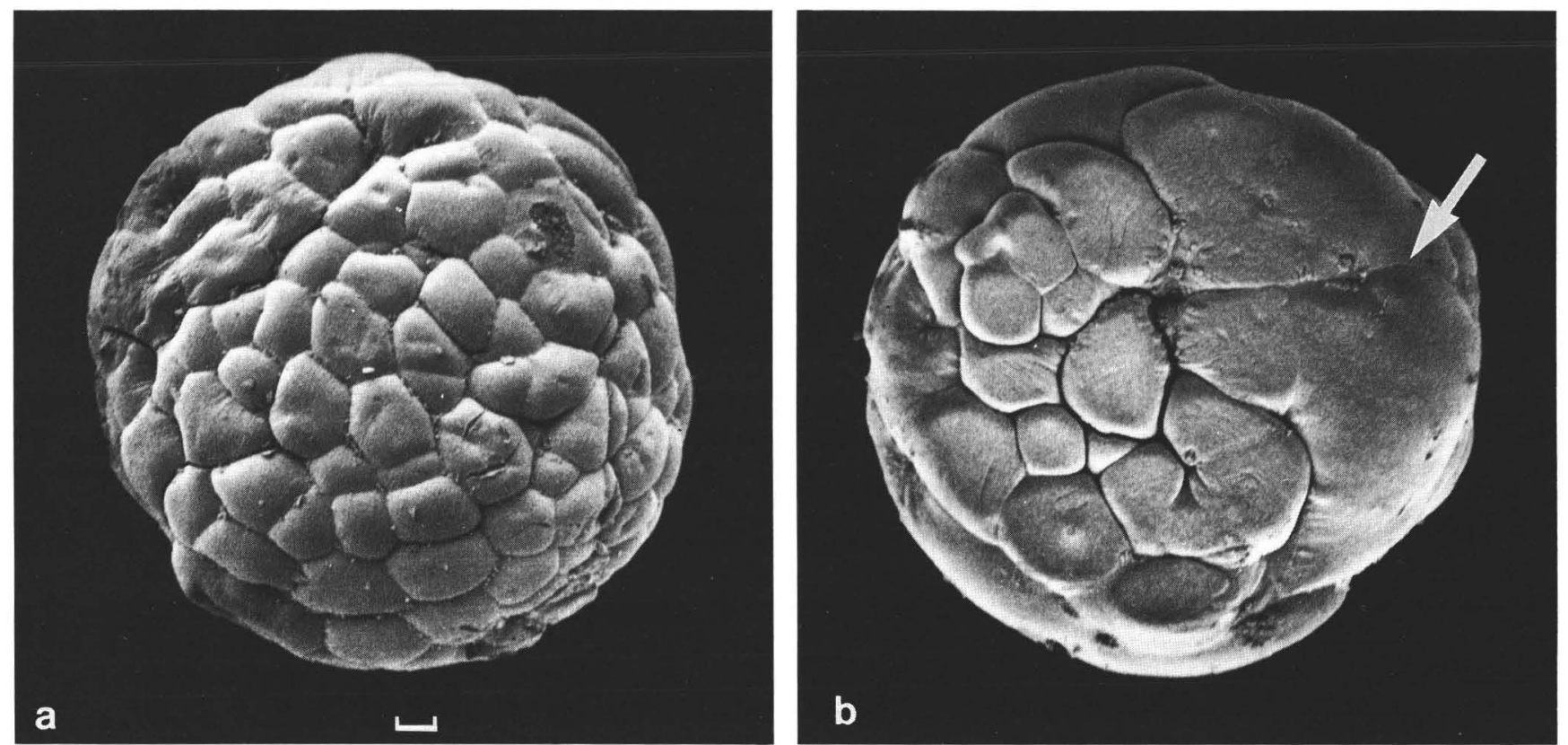

Fig. 1 a, b. Scanning electron micrographs of Xenopus embryos injected at the two cell-stage with wheat germ agglutinin (WGA) (b) or buffer alone (a). In both cases the blastomere on the right-hand side of the panel was injected and the embryos were allowed to develop for $4 \mathrm{~h}$. Buffer injection did not affect cleavage (a). In contrast, in the presence of WGA, cleavage of the blastomere was inhibited (arrow in b; a shallow cleavage furrow is indicated) while the non-injected daughter blastomere (on the left) continued development. Bar represents $50 \mu \mathrm{m}$

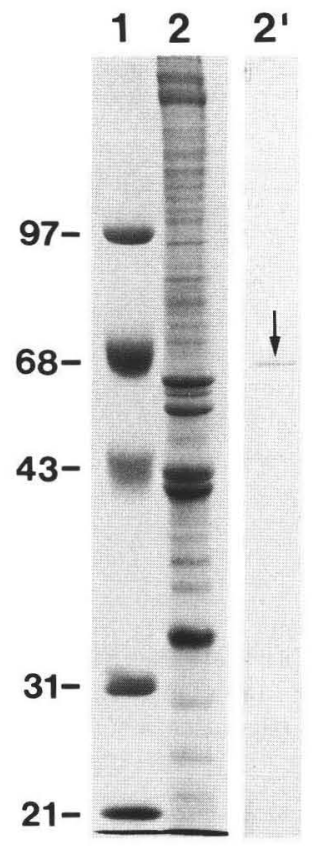

Fig. 2. Identification of rat kangaroo polypeptides reacting with antibody PI1 by one-dimensional gel electrophoresis and immunoblotting. Coomassie Blue-stained SDS-polyacrylamide gel showing polypeptides of a crude nuclear fraction from $\mathrm{PtK}_{2}$ cells (lane 2). Polypeptides from a gel run in parallel were electrophoretically transferred to a nitrocellulose filter and probed with antibody PI1. The antibody reacts specifically with a single polypeptide of $\mathrm{M}_{\mathrm{r}} 68000$ (arrow in lane $2^{\prime}$ ). Reference proteins are shown in lane 1 $\left(\mathrm{M}_{\mathrm{r}}\right.$ values $\left.\times 10^{-3}\right)$ peptide band of identical $\mathrm{M}_{\mathrm{r}}$ value has been detected with PI1 in immunoblots using isolated nuclear envelopes from Xenopus oocytes (Dabauvalle et al. 1988a) and of slightly higher electrophoretic mobility when bovine lymphocyte nuclear fractions were used as the antigen source (Chaly et al. 1984).

Indirect immunofluorescence microscopy employing antibody PI1 revealed a finely punctate staining of the nuclear periphery of interphase $\mathrm{PtK}_{2}$ cells (Fig. 3a). A similar pattern of fluorescence at the nuclear periphery had been noted when other mammalian cells and insect cells were analyzed with the same antibody (Chaly et al. 1984, 1986). A number of studies have shown that such an immunofluorescence labeling pattern is produced by pore complex-specific antibodies (Davis and Blobel 1986, 1987; Hanover et al. 1987; Park et al. 1987; Snow et al. 1987). The nucleoplasmic labeled patches detected in previous work using PI1 hybridoma culture supernatant, or unpurified PI1 ascites fluid (Chaly et al. 1984, 1986) were not observed in this study. The loss of internal nuclear labeling in PI1 antibody fractionated on an hydroxylapatite column is being investigated.

Concomitant with the disintegration of the nuclear envelope at mitosis, the antigen recognized by antibody PI1 dispersed throughout the cytoplasm in the form of numerous granular entities (Fig. 3; see also Chaly et al. 1984; Davis and Blobel 1986; Park et al. 1987; Snow et al. 1987). This dotted immunofluorescence pattern might indicate that pore complexes do not completely disintegrate during mitosis but remain at least partly assembled (Fig. 3; see Snow et al. 1987). 

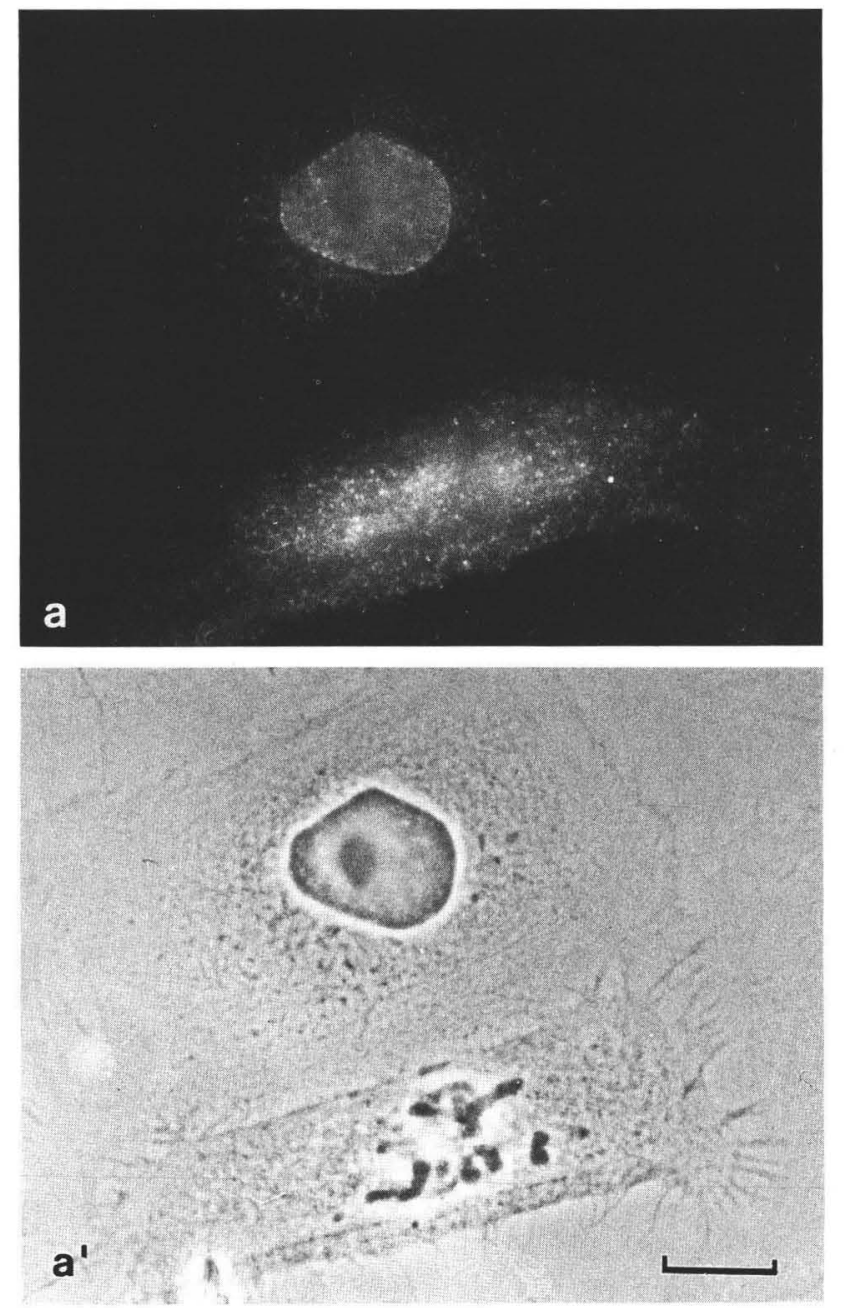

Fig. 3a, $\mathbf{a}^{\prime}$. Immunofluorescence microscopy of $\mathrm{PtK}_{2}$ cells probed with antibody PI1. The antibody stains the nuclear periphery of interphase cells in a characteristic punctate pattern (a upper cell). During mitosis, the antigen disperses in the cytoplasm (a lower cell). The corresponding phase contrast image is shown in $\left(\mathbf{a}^{\prime}\right)$. Bar represents $10 \mu \mathrm{m}$

\section{Microinjection into Pt $\mathrm{K}_{2}$ cells}

Initial experiments with $\mathrm{PtK}_{2}$ cells were designed to determine the stage of postmitotic nuclear reassembly at which newly formed nuclear pore complexes resumed transport of proteins into the daughter nuclei.

Nucleoplasmin was injected into dividing $\mathrm{PtK}_{2}$ cells at or before metaphase, and its intracellular distribution was followed by immunofluorescence microscopy. Nucleoplasmin is a well-characterized soluble protein abundantly present in oocyte nuclei of Xenopus (and other amphibians). It rapidly migrates into the nucleus of Xenopus oocytes or of non-amphibian cultured cells when microinjected into the cytoplasm (Dingwall and Laskey 1986; Peters 1986; Feldherr and Dworetzky 1988; Dabauvalle et al. 1988b). Furthermore, nuclear uptake of nucleoplasmin has been shown to occur exclusively via the pore complexes (Feldherr et al. 1984).

When $\mathrm{PtK}_{2}$ cells were microinjected at metaphase and processed for immunofluorescence a few minutes later, nucleoplasmin was distributed throughout the cytoplasm and
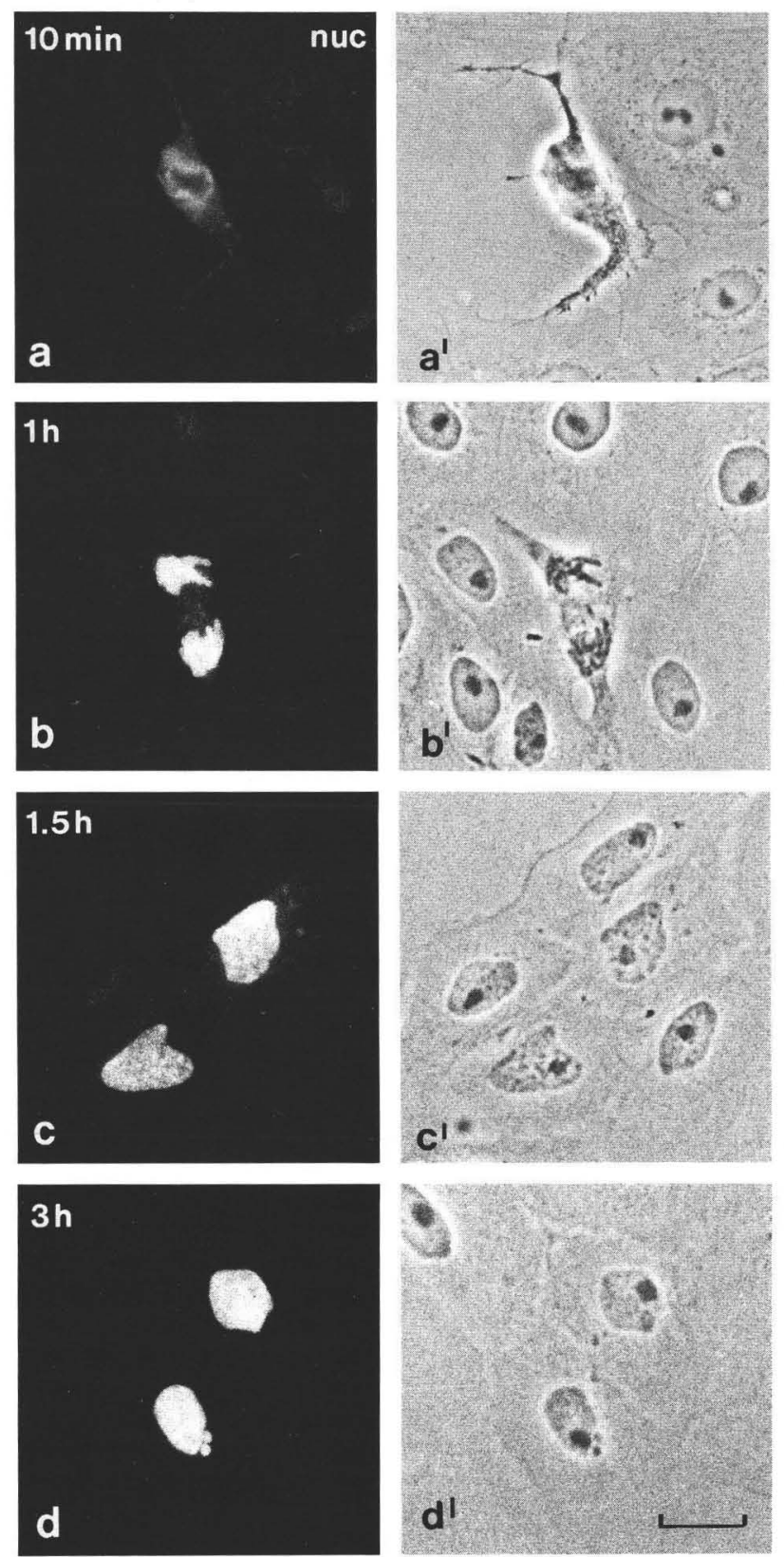

Fig. 4a-d' . Intracellular distribution of nucleoplasmin at successive time points following injection into metaphase $\mathrm{PtK}_{2}$ cells as revealed by immunofluorescence microscopy using antibodies against nucleoplasmin (a-d). The corresponding phase contrast images are shown $\left(\mathbf{a}^{\prime}-\mathbf{d}^{\prime}\right)$. Immediately after injection, nucleoplasmin $(n u c)$ is distributed throughout the cytoplasm (a) but is then efficiently taken up by the reforming nuclei as early as in telophase (b). Cells were fixed $10 \mathrm{~min}(\mathbf{a}), 1 \mathrm{~h}$ (b), $1.5 \mathrm{~h}$ (c), and $3 \mathrm{~h}$ (d) after microinjection. Completion of mitosis and transition of the daughter cells into $\mathrm{G} 1$ is not affected by the injection procedure. Bar represents $20 \mu \mathrm{m}$

was clearly excluded from the condensed chromosomes (Fig. 4a). However, when the injected cells were permitted to reach mid-telophase before processing, nucleoplasmin was sequestered to the two daughter nuclei (Fig. 4b), and remained sequestered thereafter in the reforming interphase nuclei (Fig. 4c, d). Microinjection of nucleoplasmin apparently did not negatively affect the recipient cell, since mitosis proceeded normally and the daughter cells were fully 

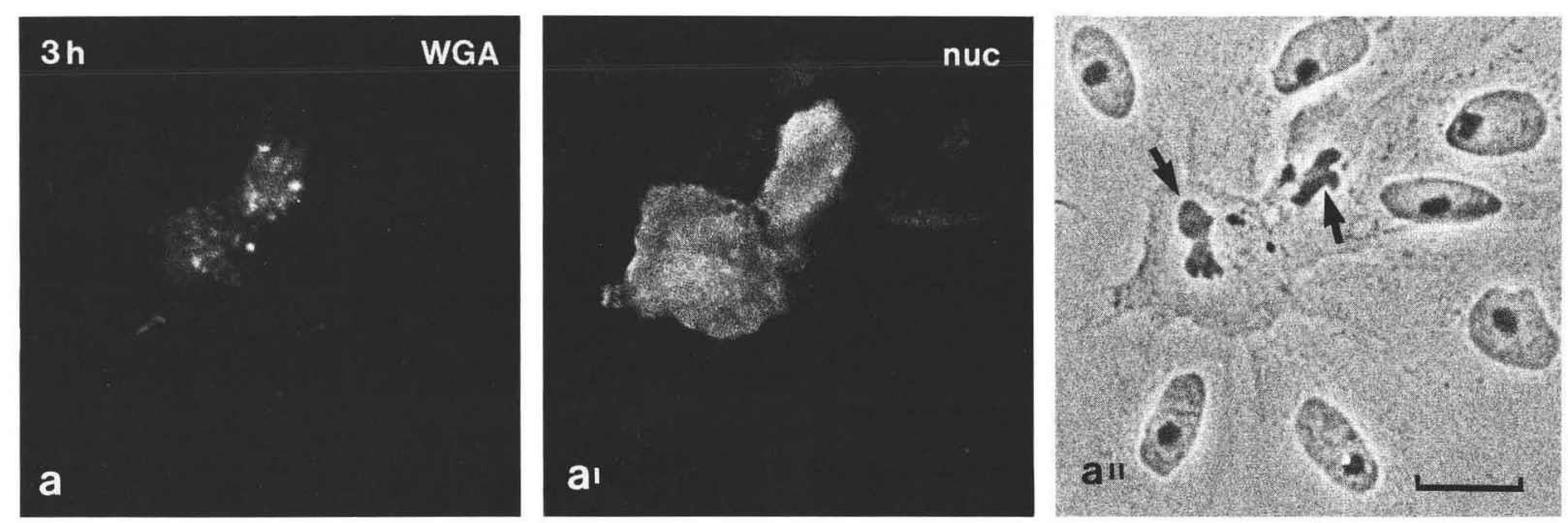

Fig. 5a-a". Inhibition of nuclear transport of nucleoplasmin by WGA in a PtK ${ }_{2}$ cell. The distribution of WGA (a) and nucleoplasmin $\left(\mathbf{a}^{\prime}\right)$ is shown $3 \mathrm{~h}$ after injection of a $2 \mathrm{mg} / \mathrm{ml}$ WGA solution into a metaphase $\mathrm{PtK}_{2}$ cell. The corresponding phase contrast image is shown in $\left(\mathbf{a}^{\prime \prime}\right)$. Nucleoplasmin $(n u c)$ fills the cytoplasm of the daughter cells $\left(\mathbf{a}^{\prime}\right)$ and is largely excluded from their nuclei which remain arrested in a highly condensed telophase-like state (arrows in $\mathbf{a}^{\prime \prime}$ ). Bar represents $20 \mu \mathrm{m}$
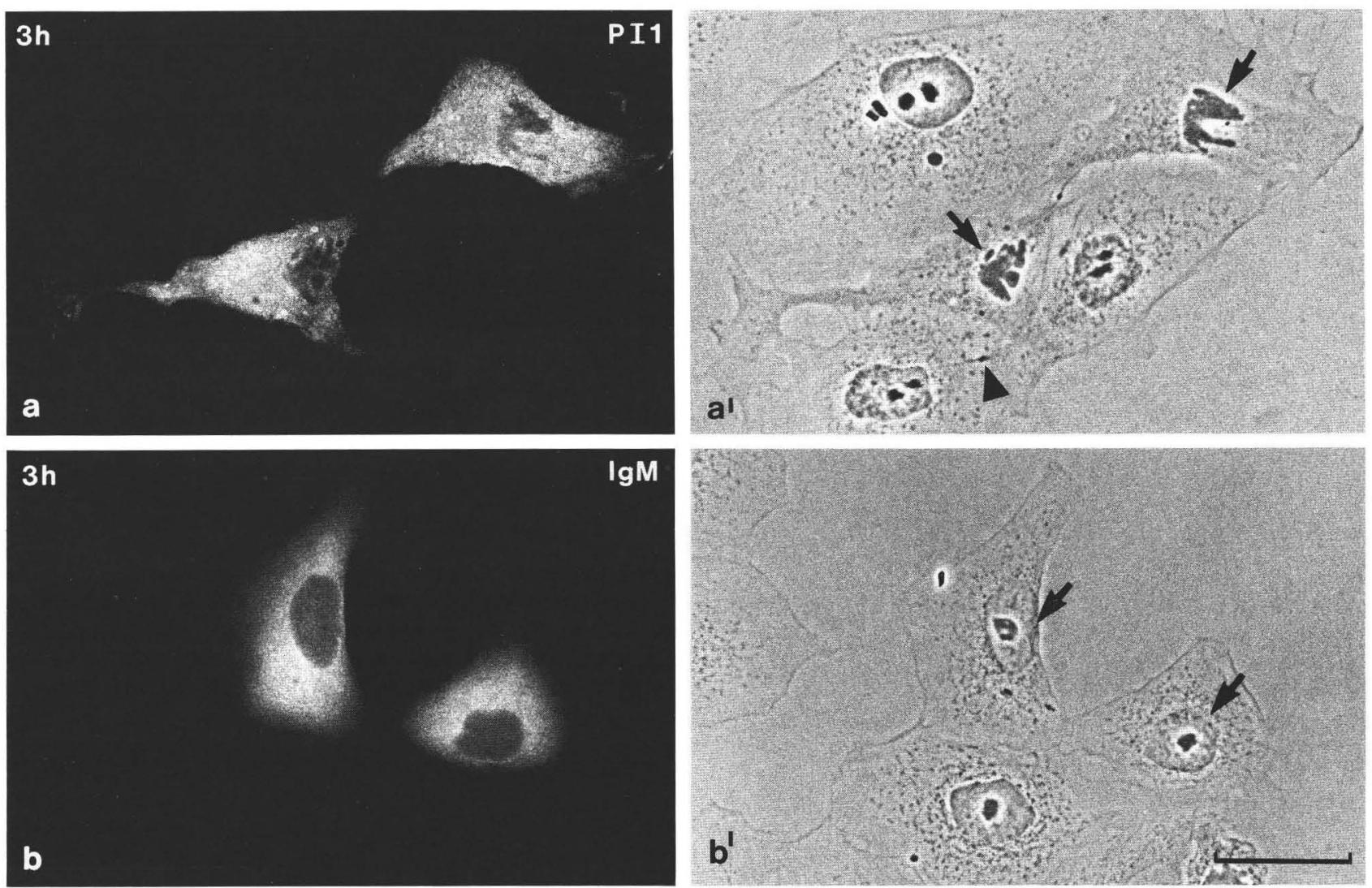

Fig. 6a-b'. Distribution and effect of antibody PI1 and non-immune murine IgM in postmitotic daughter cells $3 \mathrm{~h}$ after microinjection at $10 \mathrm{mg} / \mathrm{ml}$ each into metaphase $\mathrm{PtK}_{2}$ cells as revealed by immunofluorescence microscopy (a, b). The corresponding phase contrast images are shown in $\left(\mathbf{a}^{\prime}, \mathbf{b}^{\prime}\right)$. Note the persistence of the condensed state of chromatin of the daughter cells in the presence of the antibody (arrows in $\mathbf{a}^{\prime}$ ). Two adjacent non-injected daughter cells have already decondensed their chromatin and reformed nucleoli even though they are still connected by a cytoplasmic bridge, the midbody, indicating that the nuclei are in the early G1 phase (arrowhead in $\mathbf{a}^{\prime}$ ). Daughter cells containing non-immune IgM have entered interphase $3 \mathrm{~h}$ after injection as revealed by chromosome decondensation and nucleolar reformation (arrows in $\mathbf{b}^{\prime}$ ). Bar represents $20 \mu \mathrm{m}$

able to reorganize interphase nuclei and nucleoli (Fig. $4 \mathrm{c}^{\prime}$, $\left.\mathrm{d}^{\prime}\right)$. On the other hand, when nucleoplasmin was injected into dividing cells together with WGA or antibody PI1, its distribution essentially remained cytoplasmic. Three hours after injection, nucleoplasmin was still located in the cytoplasm of the daughter cells and was apparently unable to enter their nuclei (Fig. 5a'; compare with Fig. 4b-d).
This observation clearly illustrates the inhibitory action of both WGA and antibody PI1 on the nuclear transport machinery in mammalian cells.

Microinjected WGA or antibody PI1 also had drastic effects on the development of the postmitotic daughter nuclei (Figs. 5, 6). While cytokinesis apparently was not affected, the daughter cell nuclei still retained a telophase-like 

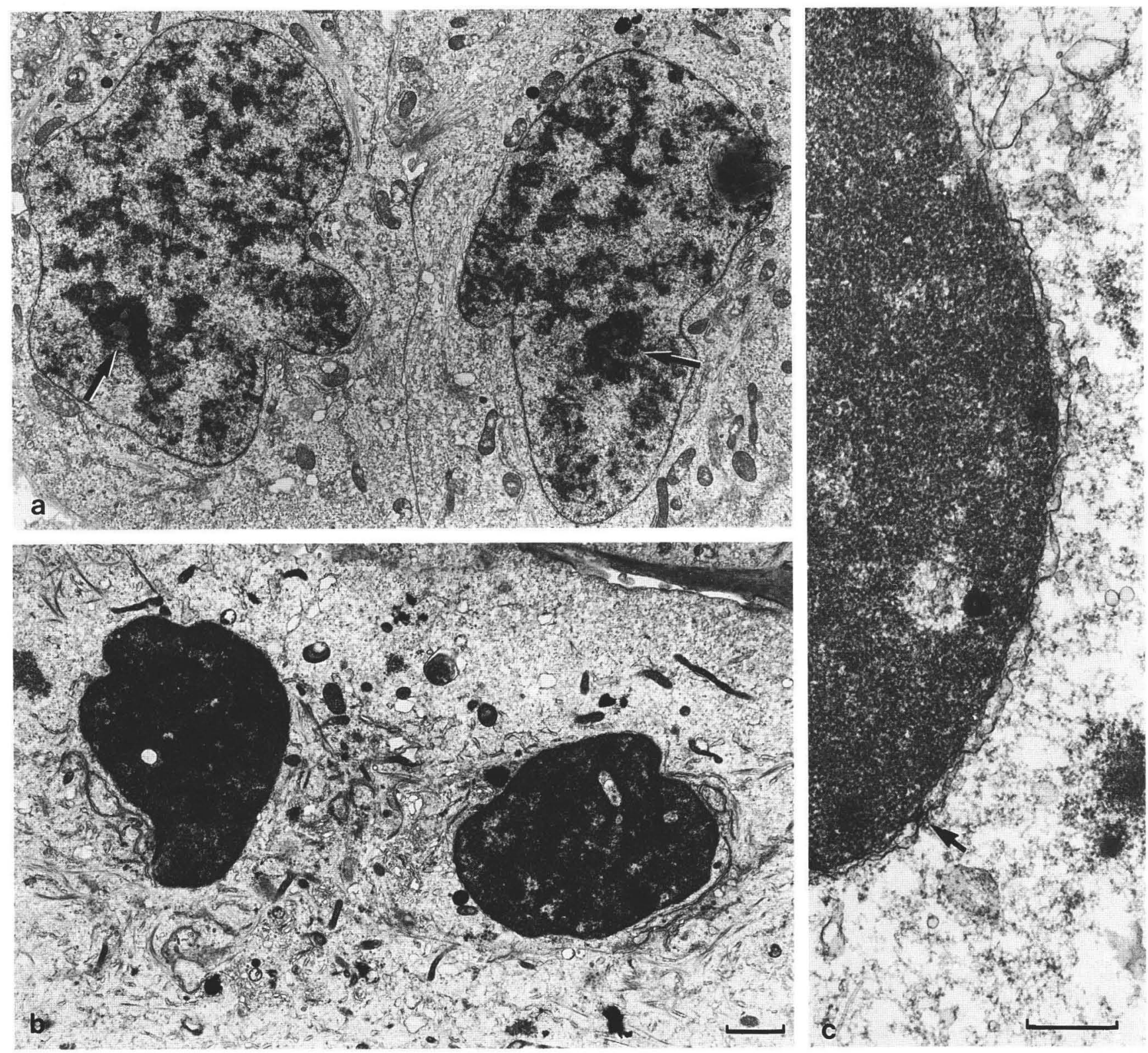

Fig. 7a-c. Electron micrographs illustrating structural features of normal daughter cells approximately $1 \mathrm{~h}$ after metaphase (a) and $3 \mathrm{~h}$ after microinjection of $2 \mathrm{mg} / \mathrm{ml}$ WGA into a metaphase $\mathrm{PtK}_{2}$ cell (b, c). Chromatin of the control nuclei is already partially decondensed and nucleoli (arrows) have reformed (a). Chromatin of injected cells maintains its highly compact conformation (b) and is surrounded by an intimately apposed double-layered membrane with a few pore complexes (c; arrow denotes a pore complex). Bars represent $1 \mu \mathrm{m}(\mathbf{a}, \mathbf{b})$, and $0.5 \mu \mathrm{m}(\mathbf{c})$

configuration with highly condensed chromosomes $3 \mathrm{~h}$ after microinjection (Figs. 5a' $6 \mathrm{a}^{\prime}$ ). Even $18 \mathrm{~h}$ after microinjection, the cells had not recovered from the arrest induced by injection of WGA or antibody PI1 (not shown).

A number of control experiments showed that the inability of the injected cells to proceed from telophase to early G1 resulted from the specific interaction of antibody PI1 with pore complex constituents. Thus, when non-immune IgM molecules were introduced into mitotic $\mathrm{PtK}_{2}$ cells, the daughter cells entered G1-phase at the normal time and their nuclei acquired characteristic interphase features such as dispersed chromatin and prominent nucleoli (Fig. 6b'). Similar results have recently been obtained with monoclonal IgM antibodies reacting with DNA (Benavente and Krohne 1986; Benavente et al. 1989).
Electron microscopy elucidated structural differences in the nuclei of daughter cells derived from injected and control cells (Fig. 7). In controls, chromatin of the daughter nuclei started to decondense shortly after completion of mitosis and nucleoli were clearly visible at approximately $1 \mathrm{~h}$ after metaphase (Fig. 7a; see also Roos 1973; Benavente et al. 1987). At $3 \mathrm{~h}$ the cells had acquired the typical interphase appearance. In contrast, chromatin of the arrested nuclei appeared extremely condensed with a packing density comparable to that of metaphase chromosomes, even at $3 \mathrm{~h}$ after metaphase (Fig. $7 \mathrm{~b}$ ). The nuclei remained small, there was little or no interchromatin material, and nucleoli were not observed. The chromatin masses were invested by a double-layered membrane with a few inserted pore complexes (Fig. $7 \mathrm{c}$ ). Although a statistical analysis 
was not performed, pore complexes seemed to be less abundant in the arrested nuclei than in normal telophase nuclei. However, a considerable number of pore complexes were visible in the cytoplasm of the arrested cells, in association with flattened membrane cisternae resembling annulate lamellae (Benavente et al. 1989).

Thus, in the absence of protein influx, newly formed daughter nuclei apparently become arrested in the telophase state, i.e., are unable to enlarge, decondense the chromosomes, reform nucleoli and develop a nucleoplasm.

\section{Discussion}

The "open" mitosis of higher eukaryotes is characterized by breakdown of the nuclear envelope at prometaphase with the concomitant loss of nucleocytoplasmic compartmentalization, and the reacquisition of this compartmentalization at telophase during nuclear envelope reformation. However, the mechanisms by which nuclear components become segregated in daughter nuclei have so far been largely hypothetical.

It is clear that some nuclear proteins bind to the mitotic chromosomes at prophase and are transmitted from one cell generation to the next as part of the chromosomes, without being released into the cytoplasm during mitosis. This pathway is not necessarily restricted to integral components of chromatin such as histones, but may also be followed by other nuclear proteins that bind transiently to the chromosomes prior to nuclear envelope breakdown. Examples of nuclear proteins that are "piggy-back" on chromosomes include a number of nucleolar components, such as RNA polymerase I (Scheer and Rose 1984; Matsui and Sandberg 1985), protein C23 or nucleolin (Lischwe et al. 1981), fibrillarin (Reimer et al. 1987), NO38 or B23 (Ochs et al. 1983; Schmidt-Zachmann et al. 1987), ribocharin (Hügle et al. 1985b) and preribosomal particles (Hügle et al. 1985a) as well as DNA topoisomerases I (Guldner et al. 1986) and II (Earnshaw and Heck 1985), perichromin (McKeon et al. 1984), and peripherin (formerly P1) (Chaly et al. 1984, 1988).

However, many nuclear proteins and RNP complexes are not chromosome bound during mitosis, but are released into the cytoplasm (see Prescott and Goldstein 1968). For instance, components of the nuclear envelope, i.e., nuclear membranes, lamins and pore complexes, are released (for review see Gerace et al. 1984; Stick 1987; see also Davis and Blobel 1986; Park et al. 1987; Snow et al. 1987; Stick et al. 1988; Wilson and Newport 1988), as are nucleoplasmin (Krohne and Franke 1980 b), a Xenopus nucleolar protein of $M_{r} 180000$ (Schmidt-Zachmann et al. 1984), SV40 large T-antigen (Gilden et al. 1965), myc protein (Winqvist et al. 1984), a mouse homeotic protein (Schulze et al. 1987), hnRNP complexes (Leser and Martin 1987), U-snRNP, or at least a certain subpopulation thereof (Reuter et al. 1985; Spector and Smith 1986; Verheijen et al. 1986) and some interchromatin nuclear matrix proteins (Chaly et al. 1984; Smith et al. 1985).

That some nucleocytoplasmic sorting of macromolecules functions at the end of mitosis is supported by our earlier observations on the localization of immunoglobulins of different binding specificities after microinjection into mitotic $\mathrm{PtK}_{2}$ cells (Benavente and Krohne 1986; see also Swanson and McNeil 1987). Thus, monoclonal antibodies directed against DNA bound to mitotic chromosomes and were therefore assembled into daughter nuclei, whereas non-immune immunoglobulins were excluded from the newly reformed nuclei (Benavente and Krohne 1986; see also Fig. 6b).

In principle, cytoplasmically dispersed nuclear proteins can be reintegrated into daughter interphase nuclei at the end of mitosis by two different pathways: by specific binding of the protein to the telophase chromosomes just prior to or during nuclear envelope formation, or alternatively, after completion of nuclear envelope formation, by transport into the nuclei through the newly assembled pore complexes.

In the present study, we have shown that the pore complexes are gateways for the postmitotic return of nuclear proteins, that resumption of nuclear protein transport is a very early postmitotic event, and, most importantly, that pore-mediated influx of endogenous proteins is essential for daughter nuclei to proceed from telophase to interphase. Furthermore, this transport must be highly efficient, since nucleoplasmin injected into the cytoplasm of metaphase $\mathrm{PtK}_{2}$ cells is almost quantitatively sequestered to daughter nuclei very early in nuclear envelope reformation, i.e. by telophase.

These conclusions are in agreement with morphological data showing the reappearance of nuclear pore complexes in early and mid-telophase of $\mathrm{PtK}_{2}$ cells (Roos 1973; see also Robbins and Gonatas 1964; Zatsepina et al. 1977) and with results obtained from cell-free nuclear reconstitution assays where pore complex formation and nuclear envelope assembly have also been shown to be intimately coupled processes (for review see Lohka 1988).

The results are also consistent with observations on nuclear reorganization in mitogen-stimulated lymphocytes, in which increases in nuclear volume, enlargement of nucleoli and the development of extensive interchromatin regions are paralleled by increases in the number and density of nuclear pores (Maul et al. 1972), the influx and quantity of non-histone nuclear proteins (Setterfield et al. 1983, 1985), and the immunofluorescence labeling pattern and intensity of antibody PI1 (Setterfield et al. 1985; Chaly et al. 1988).

This work also confirms and extends our results obtained with Xenopus oocytes showing the participation of an $M_{r} 68000$ pore complex protein in nuclear transport (Dabauvalle et al. 1988a). Antibody PI1 detects polypeptides of similar $\mathrm{M}_{\mathrm{r}}$ in Xenopus and $\mathrm{PtK}_{2}$ cells, shows similar immunofluorescence labeling patterns in the two cell types, and, when microinjected, appears to cause similar effects on nuclear transport. These data suggest that the $M_{r} 68000$ protein recognized by antibody PI1 in the nuclear periphery of $\mathrm{PtK}_{2}$ cells is homologous to the most abundant pore complex glycoprotein of Xenopus oocytes (Dabauvalle et al. $1988 \mathrm{a})$. They indicate, furthermore, that the $\mathrm{M}_{\mathrm{r}} 68000$ proteins of $\mathrm{PtK}_{2}$ and Xenopus are probably related to, if not identical with, the p62 WGA-binding nuclear pore complex glycoprotein of the rat liver (Davis and Blobel 1986; see also D'Onofrio et al. 1988; Featherstone et al. 1988).

Our experimental approach of inhibiting specifically pore-mediated nuclear transport now offers the possibility, in conjunction with the immunolocalization studies, of defining the pathway by which a defined nuclear protein migrates back into the postmitotic daughter nuclei. In particular such studies should allow us to determine whether all nuclear proteins are integrated into telophase nuclei by a 
common mechanism, or whether postmitotic nuclear targeting of some proteins occurs via transport through the nuclear pore complexes, whereas the targeting of other proteins is governed by specific interactions with telophase chromosomes prior to formation of the nuclear envelope. With this approach we hope to gain some more insights into the sequence of events leading to nuclear reformation following mitosis in the living cell (for discussion see Benavente and Krohne 1986; Lohka 1988).

Acknowledgements. We thank Georg Krohne (German Cancer Research Center, Heidelberg) for helpful suggestions and for providing nucleoplasmin antibodies, David L. Brown (University of Ottawa) for preparation of antibody PI1, and Brigitte Pilz, Hilde Merkert and Karin Loos for excellent technical assistance. This work received financial support from the Deutsche Forschungsgemeinschaft (SFB 176) and the Natural Sciences and Engineering Research Council of Canada.

\section{References}

Benavente R, Krohne G (1986) Involvement of nuclear lamins in postmitotic reorganization of chromatin as demonstrated by microinjection of lamin antibodies. J Cell Biol 103:1847-1854

Benavente R, Rose KM, Reimer G, Hügle-Dörr B, Scheer U (1987) Inhibition of nucleolar reformation after microinjection of antibodies to RNA polymerase I into mitotic cells. J Cell Biol $105: 1483-1491$

Benavente R, Scheer U, Chaly N (1989) Nucleocytoplasmic sorting of macromolecules following mitosis: fate of nuclear constituents after inhibition of pore complex function. Eur J Cell Biol (in press)

Bonner WM (1978) Protein migration and accumulation in nuclei. In: Busch H (ed) The cell nucleus, vol 6. Academic Press, New York, pp 97-148

Chaly N, Bladon T, Setterfield G, Little JE, Kaplan JG, Brown DL (1984) Changes in distribution of nuclear matrix antigens during mitotic cell cycle. J Cell Biol 99:661-671

Chaly N, Sabour MP, Silver JC, Aichison WA, Little JE, Brown DL (1986) Monoclonal antibodies against nuclear matrix detect nuclear antigens in mammalian, insect and plant cells: an immunofluorescence study. Cell Biol Int Rep 10:421-428

Chaly N, Cardin M, Kaplan JG, Brown DL (1988) Modulation of lymphocyte nuclear matrix organization in vivo by 5,6-dichloro-1- $\beta$-D-ribofuranosylbenzimidazole: An autoradiographic and immunofluorescence study. Biol Cell 63:9-17

Dabauvalle MC, Benavente R, Chaly N (1988a) Monoclonal antibodies to a $M_{r} 68000$ pore complex glycoprotein interfere with nuclear protein uptake in Xenopus oocytes. Chromosoma 97:193-197

Dabauvalle MC, Schulz B, Scheer U, Peters R (1988b) Inhibition of nuclear accumulation of karyophilic proteins in living cells by microinjection of the lectin wheat germ agglutinin. Exp Cell Res 174:291-296

Davis LI, Blobel G (1986) Identification and characterization of a nuclear pore complex protein. Cell 45:699-709

Davis LI, Blobel G (1987) Nuclear pore complex contains a family of glycoproteins that includes $\mathrm{p} 62$ : glycosylation through a previously unidentified cellular pathway. Proc Natl Acad Sci USA $84: 7552-7556$

Dingwall C, Laskey RA (1986) Protein import into the cell nucleus. Annu Rev Cell Biol 2:367-390

D'Onofrio M, Starr CM, Park MK, Holt GD, Haltiwanger RS, Hart GW, Hanover JA (1988) Partial cDNA sequence encoding a nuclear pore protein modified by O-linked N-acetylglucosamine. Proc Natl Acad Sci USA 85:9595-9599

Earnshaw WC, Heck MMS (1985) Localization of topoisomerase II in mitotic chromosomes. J Cell Biol 100:1716-1725

Featherstone C, Darby MK, Gerace L (1988) A monoclonal anti- body against the nuclear pore complex inhibits nucleocytoplasmic transport of protein and RNA in vivo. J Cell Biol 107:1289-1297

Feldherr CM, Dworetzky SI (1988) The pore complex in nucleocytoplasmic exchange. Cell Biol Int Rep 12:791-808

Feldherr CM, Kallenbach E, Schultz N (1984) Movement of a karyophilic protein through the nuclear pores of oocytes. J Cell Biol 99:2216-2222

Finlay DR, Newmeyer DD, Price TM, Forbes DJ (1987) Inhibition of in vitro nuclear transport by a lectin that binds to nuclear pores. J Cell Biol 104:189-200

Franke WW, Grund C, Osborn M, Weber K (1978) The intermediate-sized filaments in rat kangaroo $\mathrm{PtK}_{2}$ cells. I. Morphology in situ. Cytobiologie 17:365-391

Gerace L, Comeau C, Benson M (1984) Organization and modulation of nuclear lamina structure. J Cell Sci 1 (Suppl):137-160

Gilden RV, Carp RI, Taguchi F, Defendi V (1965) The nature and localization of the SV40-induced complement-fixing antigen. Proc Natl Acad Sci USA 53:684-692

Goldstein L (1974) Movement of molecules between nucleus and cytoplasm. In: Busch H (ed) The cell nucleus, vol 1. Academic Press, New York, pp 387-438

Guldner HH, Szostecki C, Vosberg HP, Lakomek HJ, Penner E, Bautz FA (1986) Scl 70 autoantibodies from scleroderma patients recognize a $95 \mathrm{kDa}$ protein identified as DNA topoisomerase I. Chromosoma 94:132-138

Gurdon JB (1986) Nuclear transplantation in eggs and oocytes. J Cell Sci 4 (Suppl):287-318

Hanover JA, Cohen CK, Willingham MC, Park MK (1987) Olinked N-acetylglucosamine is attached to proteins of the nuclear pore. J Biol Chem 262:9887-9894

Harris H (1974) Nucleus and cytoplasm. Clarendon Press, Oxford

Hart GW, Holt GD, Haltiwanger RS (1988) Nuclear and cytoplasmic glycosylation: novel saccharide linkages in unexpected places. Trends Biochem Sci 13:380-384

Hügle B, Hazan R, Scheer U, Franke WW (1985a) Localization of ribosomal protein $\mathrm{S} 1$ in the granular component of the interphase nucleolus and its distribution during mitosis. J Cell Biol $100: 873-886$

Hügle B, Scheer U, Franke WW (1985b) Ribocharin: a nuclear $M_{r} 40000$ protein specific to precursor particles of the large ribosomal subunit. Cell $41: 615-627$

Krohne G (1985) Immunological identification of the karyophilic, histone-binding proteins N1 and N2 in somatic cells and oocytes of diverse amphibia. Exp Cell Res 158:205-222

Krohne G, Franke WW (1980a) Immunological identification of the predominant nuclear protein of the amphibian oocyte nucleus. Proc Natl Acad Sci USA 77:1034-1038

Krohne G, Franke WW (1980b) A major soluble acidic protein located in nuclei of diverse vertebrate species. Exp Cell Res 129:167-189

Laemmli UK (1970) Cleavage of structural proteins during the assembly of bacteriophage T4. Nature 227:680-685

Leser GP, Martin TE (1987) Changes in heterogeneous nuclear RNP core polypeptide complements during cell cycle. J Cell Biol 105:2083-2094

Lischwe MA, Richards RL, Busch RK, Busch H (1981) Localization of phosphoprotein $\mathrm{C} 23$ to nucleolar structures and to nucleolus organizer regions. Exp Cell Res 136:101-109

Lohka MJ (1988) The reconstitution of nuclear envelopes in cellfree extracts. Cell Biol Int Rep 12:833-848

Matsui S, Sandberg AA (1985) Intranuclear compartimentalization of DNA-dependent RNA polymerases: association of RNA polymerase I with nucleolar organizing chromosomes. Chromosoma 92:1-6

Maul GG, Maul HSM, Scogna JE, Lieberman MW, Shein GS, Hsu BYL, Brown TW (1972) Time sequence of nuclear pore formation in phytohaemagglutinin-stimulated lymphocytes and in HeLa cells during cell cycle. J Cell Biol 55:433-447

McKeon FD, Tuffanelli DL, Kobayasu S, Kirschner MW (1984) The redistribution of a conserved nuclear envelope protein dur- 
ing the cell cycle suggests a pathway for chromosome condensation. Cell 36:83-92

Newmeyer DD, Forbes DJ (1988) Nuclear import can be separated into distinct steps in vitro: nuclear pore binding and translocation. Cell 52:641-653

Newport J, Kirschner M (1982) A major developmental transition in early Xenopus embryos: I. Characterization and timing of cellular changes at the midblastula stage. Cell 30:675-686

Ochs RL, Lischwe M, O'Leary P, Busch H (1983) Localization of nucleolar phosphoproteins B23 and C23 during mitosis. Exp Cell Res 146:139-149

Park MK, D’Onofrio M, Willingham MC, Hanover JA (1987) A monoclonal antibody against a family of nuclear pore proteins (nucleoporins): O-linked $\mathrm{N}$-acetylglucosamine is part of the immunodeterminant. Proc Natl Acad Sci USA $84: 6462-6466$

Peters R (1986) Fluorescence microphotolysis to measure nucleocytoplasmic transport and intracellular mobility. Biochim Biophys Acta 864:305-359

Prescott D, Goldstein L (1968) Proteins in nucleocytoplasmic interactions. III. Redistributions of nuclear proteins during and following mitosis in Amoeba proteus. J Cell Biol 39:404 414

Reimer G, Pollard KM, Pennig CA, Ochs RL, Lischwe MA, Busch H, Tan EM (1987) Monoclonal autoantibody from NZB/NZW F1 mouse and some human scleroderma sera target a $M_{r} 34000$ nucleolar protein of the U3-ribonucleoprotein particle. Arthritis Rheum 30:793-800

Reuter R, Appel B, Rinke J, Lührmann R (1985) Localization and structure of snRNPs during mitosis. Immunofluorescent and biochemical studies. Exp Cell Res 159:63-79

Ringertz NR, Savage RE (1976) Cell hybrids. Academic Press, New York

Robbins E, Gonatas NK (1964) The ultrastructure of a mammalian cell during the mitotic cycle. J Cell Biol 21:429-463

Roos UP (1973) Light and electron microscopy of rat kangaroo cells in mitosis. I. Formation and breakdown of the mitotic apparatus. Chromosoma 40:43-82

Scheer U, Rose KM (1984) Localization of RNA polymerase I in interphase cells and mitotic chromosomes by light and electron microscopic immunocytochemistry. Proc Natl Acad Sci USA $81: 1431-1435$

Scheer U, Lafranchi G, Rose KM, Franke WW, Ringertz NR (1983) Migration of rat RNA polymerase I into chick erythrocyte nuclei undergoing reactivation in chick-rat heterokaryons. J Cell Biol 97:1641-1643

Scheer U, Dabauvalle MC, Merkert H, Benavente R (1988) The nuclear envelope and the organization of the pore complexes. Cell Biol Int Rep 12:669-688

Schmidt-Zachmann MS, Hügle B, Scheer U, Franke WW (1984) Identification and localization of a novel nucleolar protein of high molecular weight by a monoclonal antibody. Exp Cell Res 153:327-346

Schmidt-Zachmann MS, Hügle-Dörr B, Franke WW (1987) A constitutive nucleolar protein identified as a member of the nucleoplasmin family. EMBO J 6:1881-1890

Schulze F, Chowdhury K, Zimmer A, Drescher U, Gruss P (1987) The murine homeo box gene product, Hox 1.1 protein, is growth-controlled and associated with chromatin. Differentiation $36: 130-137$

Setterfield G, Hall R, Bladon T, Little J, Kaplan JG (1983) Changes in structure and composition of lymphocyte nuclei during mitogenic stimulation. J Ultrastruct Res 82:264-282

Setterfield G, Bladon T, Chaly N, Brasch K, El Ansary H, Brown
DL (1985) Extrachromatin nuclear components and structural changes in nuclei. In: Nuclear envelope structure and RNA maturation. Smuckler EA, Clawson GS (eds) UCLA Symp Mol Cell Biol New Series, vol 26. Allan R Liss, New York, pp 63-86 Smith HC, Spector DL, Woodcock CLF, Ochs RL, Bhorjee J (1985) Alterations in chromatin conformation are accompanied by reorganization of nonchromatin domains that contain UsnRNP protein p28 and nuclear protein p107. J Cell Biol $101: 560-567$

Snow CM, Senior A, Gerace L (1987) Monoclonal antibodies identify a group of nuclear pore complex glycoproteins. J Cell Biol 104:1143-1156

Spector DL, Smith HC (1986) Redistribution of U-snRNPs during mitosis. Exp Cell Res 163:87-94

Stanker LH, Nander Caan M, Juarez-Salinas H (1985) One-step purification of mouse monoclonal antibodies from ascites by hydroxylapatite chromatography. J Immunol Methods 76:157-169

Stick R (1987) Dynamics of the nuclear lamina in mitosis and meiosis. In: Schlegel RA, Halleck MS, Rao PN (eds) Molecular regulation of nuclear events in mitosis and meiosis. Academic Press, Orlando, pp 43-66

Stick R, Angres B, Lehner CF, Nigg EA (1988) The fates of chicken nuclear lamin proteins during mitosis: evidence for a reversible redistribution of lamin $B_{2}$ between inner nuclear membrane and elements of the endoplasmic reticulum. J Cell Biol 107:397-406

Swanson JA, McNeil PL (1987) Nuclear reassembly excludes large macromolecules. Science 238:548-550

Towbin H, Staehlin T, Gordon J (1979) Electrophoretic transfer of proteins from polyacrylamide gels to nitrocellulose sheets: procedure and some applications. Proc Natl Acad Sci USA $76: 4350-4354$

Verheijen R, Kuijpers H, Vooijs P, van Venrooij W, Ramaekers F (1986) Distribution of the 70K U1 RNA-associated protein during interphase and mitosis. Correlation with other U RNP particles and proteins of the nuclear matrix. J Cell Sci $86: 173-190$

Wilson KL, Newport J (1988) A trypsin-sensitive receptor on membrane vesicles is required for nuclear envelope formation in vivo. J Cell Biol 107:57-68

Winquist R, Saksela K, Alitalo K (1984) The myc proteins are not associated with chromatin in mitotic cells. EMBO J $3: 2947-2950$

Wolff B, Willingham MC, Hanover JA (1988) Nuclear protein import: specificity for transport across the nuclear pore. Exp Cell Res 178:318-334

Woodcock CLF, Lafond RE, Woodcock H, Baldwin LA, Bhorjee JS (1984) Reactivation of avian erythrocyte nuclei in mammalian cytoplasts. A dominant role for pre-existing cytoplasmic components. Exp Cell Res 154:155-170

Yoneda Y, Imamoto-Sonobe N, Yamaizumi M, Uchida T (1987) Reversible inhibition of protein import into the nucleus by wheat germ agglutinin injected into cultured cells. Exp Cell Res 173:586-595

Zatsepina OV, Polyakov VY, Chentsov YS (1977) Some structural aspects on the fate of the nuclear envelope during mitosis. Cytobiologie 16:130-144

Received June 9, 1989 / in revised form August 2, 1989

Accepted by W. Hennig 